\title{
FROM MITIGATION TO SUSTAINABILITY: THE EVOLUTION OF INCORPORATING ENVIRONMENTAL FACTORS INTO DEVELOPMENT DECISIONS IN AUSTRALASIA
}

\author{
B.R. JENKINS \\ Waterways Centre for Freshwater Management, University of Canterbury and Lincoln University, \\ New Zealand.
}

ABSTRACT

This paper discusses the evolution of techniques to incorporate environmental factors into development decisions. The paper initially describes the introduction of environmental impact assessment (EIA) and its role in mitigating adverse environmental effects of projects. It then describes the expansion into project operations with environmental audits, and considering developments in their regional context through site selection and rehabilitation EIA, and state of environment reporting. The next stage of the evolution of techniques that is identified is the introduction of strategic environmental assessments (SEAs) bringing environmental considerations into decision making at an earlier stage in the development process.

However, effects-based legislation from which these instruments were drawn has not stopped the progressive degradation of the environment. This has led to the concept of regional sustainability strategies as a proactive approach to sustainable development rather than the reactive approach of EIA in response to development proposals. The example of the Canterbury Water Management Strategy (CWMS) as a regional sustainability strategy is described. Then, the application of the resources/processes/outcomes/response approach to the sustainability of operational activities in Canterbury is also presented.

The evolution of environmental instruments from mitigation to sustainability is summarized and examples of innovative approaches needed to manage at sustainability limits are identified.

Keywords: environmental impact assessment, environmental instruments, sustainability limits, sustainability strategies.

\section{INTRODUCTION OF ENVIRONMENTAL IMPACT ASSESSMENT}

A major change in environmental decision making occurred in 1969 with the passage of the National Environmental Policy Act in USA. This Act introduced a new requirement for US Federal government agencies proposing an action [1]. The requirement was the preparation of an environmental impact statement. This required the preparation a detailed statement on:

i. The environmental impact of the proposed action,

ii. Any adverse environmental effects which cannot be avoided should the proposal be implemented,

iii. Alternatives to the proposed action,

iv. The relationship between local short-term uses of man's environment and the maintenance and enhancement of long-term productivity, and 
v. Any irreversible and irretrievable commitments of resources which would be involved in the proposed action should it be implemented.

The concept of environmental impact assessment (EIA) and effects-based management spread internationally. While the procedures vary from country to country the introduction of a mechanism to consider the environmental effects of proposed actions was a major shift in introducing environmental factors into development decision making.

Australia and New Zealand introduced their own variants of effects-based legislation. Effects-based legislation in Australasia contains terms like "avoiding, remedying or mitigating any adverse effects of activities on the environment" [2] or "prevent, control and abate pollution and environmental harm" [3].

The introduction of environmental information through EIA can change projects. Jenkins [4] provided examples of different ways in which the consideration of environmental information influenced development projects. The degree of influence varied from no influence to shelving the project. The noise footprint analysis for the Geelong Regional Airport demonstrated that noise levels were well within acceptable standards for nearby residential areas and the project required no change to address environmental effects. The environmental investigations for a proposed resort development at Byron Bay identified that the site was within a coastal hazard zone: this led to the project being shelved.

Techniques such as constraint mapping influenced site layout decisions. The layout of the proposed petrochemical plant at Point Wilson was changed to avoid the prime wintering habitat of the Orange-bellied Parrot, a rare and endangered species with only about 100 birds remaining.

Environmental considerations can also lead to redesign. In the preliminary engineering design for the Pine Creek gold mine, the various waste and water management facilities were initially considered as separate design problems and were located to minimise haulage costs. The environmental investigations found that the tailings dam was sited in a water supply catchment, that the overburden dump crossed drainage channels leading to the potential for acid mine drainage, and, that the available groundwater supply was limited. This resulted in the redesign for an integrated arrangement of waste and water management facilities which avoided water supply catchments, recycled tailings supernatant as process water, and, diverted floodwaters from tailings and overburden storage.

Mitigation measures were also a common addition to development projects. An example is a quarry at Pakenham. Mitigation measures included: staging and plantings to screen quarrying from most views; constructing barriers for noise and dust control; sealing roads to reduce dust generation; progressive revegetation to reduce erosion; a sedimentation basin to reduce turbidity; and, water sprays for dust suppression.

\section{EXPANSION TO OPERATIONS AND REGIONAL CONTEXT}

EIA typically led to conditions on projects. There were also pollution controls (in Australia) and consent conditions (in New Zealand) which led to operational requirements for projects. One development was environmental audits. In Australia there were three main types: (1) Audits of environmental impacts involving the monitoring actual impact levels to compare with predictions from environmental assessments; (2) Audits of industrial premises involving the review of discharges and waste management practices of industrial facilities; and (3) Site contamination audits involving the assessment of past contamination of soil usually in relation to a change in land use or change in land ownership [5]. 
There were also examples that considered the relationship of projects within their regional context. One common example was EIA on site selection, for example, the site selection of the second Sydney Airport [6]. The entire Sydney region was reviewed for potential sites for a second airport. The suitability of potential sites was then evaluated by multi-criteria analysis. Another example was on rehabilitation after industry closure, e.g. the Penrith Lakes proposal [7]. The proposal involved the coordination and rehabilitation of a large area of sand and gravel extraction to create a major water-oriented recreation resource. The remediation of contaminated sites also fits into this category. Environmental legislation was extended to address past contamination from existing development (as distinct from potential contamination from new development that was addressed by impact assessment legislation). This involved the introduction of trigger points for identifying contaminated sites, determination of liability for contamination, requirements for disclosure, provisions for investigation and remediation, and validation of remediation [8].

Another environmental instrument, State of Environment Reports which performed the equivalent of environmental audits at the region, state or national level demonstrated ongoing degradation of the environment. The reports were based on the "Pressure-State-Response model" from the OECD [9] but the emphasis was primarily of the "state" component.

\section{STRATEGIC ENVIRONMENTAL ASSESSMENT}

An evolution in environmental practice to bring environmental considerations earlier into the development decision-making process was strategic environmental assessment (SEA). SEA refers to a systematic process of analysing the environmental effects of policies, plans and programmes [10]. In Australasia, this was first introduced in Western Australia in 1995 as advice to the Minister. The WA Environmental Protection Act was amended in 2003 to allow formal assessment of strategic proposals.

One area where SEAs were effective was in relation to managing environmental effects of industrial proposals. SEAs were conducted for industrial estates in areas where industrial plants were anticipated. This enabled identifying issues in advance of development proposals and allowed time for baseline studies and investigations of potential environmental problems as well defining appropriate buffer zones for issues like noise. One example was the siting of the Geraldton Steel Plant proposal within the Oakajee Industrial Estate. This facilitated the avoidance of sensitive environmental areas and the creation of appropriate buffer zones in advance of the steel plant proposal. It also enabled the undertaking of hydrological investigations to determine the acceptability of liquid waste treatment in an area of limestone.

\section{MANAGEMENT OF EFFECTS AT SUSTAINABILITY LIMITS}

Effects-based legislation does not require elimination of adverse effects. Instead we see terms like preventing "significant adverse effects on the environment" [11], conditions to address "material environmental harm" [12], or ensure adverse effects "are no more than minor" [13]. This allows small adverse effects for projects that are approved. Notwithstanding, the cumulative outcome is for ongoing degradation of the environment. Many jurisdictions in Australia and New Zealand also have environmental protection policies that set environmental limits for environmental outcomes. However, effects-based legislation allows for extraction or discharge up to and even beyond the limits.

Two New Zealand examples are considered below. One is in relation to water availability limits - the extraction of groundwater from the Rakaia-Selwyn groundwater zone. The other 
in relation to the cumulative effects of land-use intensification on water quality - nitrate levels in the Selwyn River catchment.

The Rakaia-Selwyn groundwater zone is part of the Canterbury Plains unconfined aquifer system. There has been a significant increase in groundwater extraction primarily associated with the expansion of dairying. Groundwater allocation limits had been defined based on protecting flows of groundwater-fed streams [14]. When the effective allocation for use of current consents exceeded the groundwater allocation limits, the regional council recommended that further consent applications for extraction from a groundwater zone be declined.

The first resource consent application affected by this recommendation was by Lynton Dairy. It was for a large volume of water in terms of a single consent application and represented about $2 \%$ of the total consented water volume in the Rakaia-Selwyn groundwater zone. The application was declined by hearing commissioners consistent with the council recommendation. The applicant appealed the recommendation to the Environment Court. The Court determined that because field measurements of flow have a measurement uncertainty of $\pm 5 \%$, there was no probative evidence of an adverse effect (i.e. you couldn't measure a $2 \%$ change). The Court granted $70 \%$ of the volume sought by the applicant [15].

Subsequent decisions on further groundwater extraction applications by hearing commissioners and the Environment Court now mean that the effective allocation associated with groundwater consents is now $134 \%$ of the groundwater allocation limit [16].

The water quality example is the Central Plains Water Irrigation Scheme where nitrate leaching into groundwater from land use intensification was a significant concern. Groundwater is used for drinking water supplies and feeds lowland streams that discharge into a coastal lake. At the time of the hearings for the consent application, 3\% of the monitoring wells exceeded the nitrate standard for drinking water $(11.3 \mathrm{mg} / \mathrm{L})$. In relation to nitrate toxicity, nitrate concentrations in the lower reaches of the Selwyn River exceeded the threshold for chronic toxicity of highly disturbed systems in environments that are considered measurably degraded (3.6 mg/L nitrate nitrogen median value). For algae in lowland streams the maximum limit for chlorophyll a is $200 \mathrm{mg} / \mathrm{m}^{2}$. This is exceeded $95 \%$ of the time in the Selwyn River. The coastal lake had a Trophic Level Index of 7.0 while the objective was to achieve a TLI of 6.0. The catchment already exceeded the sustainability limits for water quality.

The hearing commissioners acknowledged that the Scheme would increase nitrate concentrations in the aquifer, lowland streams and coastal lake. They also acknowledged that nitrate levels would be further increased from recent intensification because of the time lag in groundwater transport. They noted the conflict of the Scheme with water quality objectives and policies but considered the likely adverse effects would be minor. The consent was granted subject to the adoption of best management practices through Farm Environmental Plans to mitigate the impacts of land use intensification [17].

Subsequent cumulative effects analysis estimated that the current nitrogen load to the lake is 2,650 tN/yr. The equilibrium load (i.e., allowing for the time lag in groundwater transport) for the 2011 land use is estimated to be 4,100 tN/yr. With the addition of Central Plains Water Irrigation Scheme and from further gradual intensification the load is estimated to be $5,600 \mathrm{tN} / \mathrm{yr}$ [18]. This is more than double the nitrogen load where the sustainability limits of water quality have been exceeded.

\section{CANTERBURY REGIONAL STRATEGIES}

While the cumulative effects of resource abstraction and resource use are within sustainability limits effects-based assessment of new development, which allows minor increases in 
resource abstraction or resource use, can be sufficient for environmental management purposes. However, once sustainability limits have been reached, then any further increase has unacceptable adverse effects. Thus, future development even with minor adverse effects will be unacceptable.

The concept of regional sustainability strategies was developed to address this issue [19]. Rather than deal with just new development, the focus is upon resource availability and use at the appropriate biophysical scale, e.g. watershed or airshed.

The Canterbury Water Management Strategy (CWMS) [20] was formulated because of the failure of the Resource Management Act (RMA) to provide an adequate basis for managing irrigation development in the Canterbury region. Sustainability limits were being reached in terms of water availability for both surface water withdrawals and groundwater abstraction, and in terms of land-use intensification from irrigation with respect to impacts on water quality and freshwater ecology [21].

The process was designed to be collaborative involving multiple stakeholders (rather than applicant-driven as in EIA) [22]. The process was overseen by a multi-stakeholder group under the auspices of the Canterbury Mayoral Forum. The strategic framework was developed through stakeholder and community engagement (rather than as proponents and opponents in an EIA statutory process). It generated a shift from addressing water availability through storage on alpine rivers to a strategy to address targets for 10 community priority issues related to water. The 10 issues were: ecosystem health/biodiversity, natural character of braided rivers, kiatiakitanga*, drinking water, recreational and amenity opportunities, water-use efficiency, irrigated land area, energy security and efficiency, regional and national economies, environmental limits.

Potential strategies to deliver on the targets were evaluated by sustainability appraisal which considered sustainability bottom lines for environmental, economic, social and cultural criteria and desirable top lines for the same criteria [23]. The sustainability appraisal found that:

- "Business as usual" under the RMA did not achieve the sustainability bottom line.

- A storage-led strategy scored well on economic criteria but not on environmental criteria.

- An environment-led strategy opposed to storage until environmental issues were addressed scored well on environmental criteria but not economic criteria.

- An efficiency-led option making water available from improved efficiency of currently allocated water thereby reducing contamination from surface water and groundwater leakage, scored above the sustainability bottom line on nearly all criteria.

The key outcomes of the sustainability appraisal for a regional strategy were that:

- It is only possible to achieve sustainable development by considering existing uses of water as well as new uses and projects (i.e. EIA on new developments is not enough).

- The most economically viable source of additional water was from efficiency gains from existing users rather than storage (i.e. changes are required by existing users who have legal rights to water allocations from EIA processes).

- Environmental requirements were best met by improved land use practices of existing and new users (i.e. changes are required by existing users to management approaches accepted through EIA processes).

\footnotetext{
* Kiatiakitanga means the exercise of guardianship of resources based on Maori custom
} 


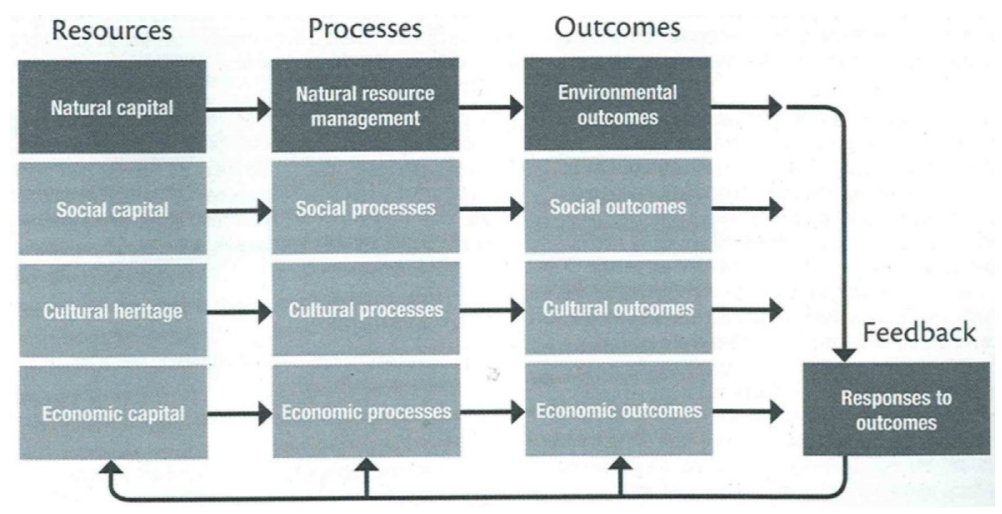

Figure 1: Framework for reporting sustainability outcomes.

- There is no capacity for further land-use intensification unless the cumulative effects of existing users are reduced (i.e. any adverse effect of new development exceeds environmental limits).

- There is a need for parallel development of environmental restoration with water resource development (i.e. proactive restoration is needed not just mitigation of adverse effects).

A collaborative community-based approach to the formulation of implementation programmes to deliver the strategy was established through ten Zone Committees of community members and rununga* ${ }^{* *}$ representatives, and a Regional Committee of multiple stakeholders.

One example of the proactive approach to the parallel development of environmental restoration is the "Immediate Steps Biodiversity" programme. The Zone Committees were to identify priority restoration projects within their zone and the Region Committee was to identify priority projects for the region. The projects were to be drawn from the Regional Biodiversity Strategy [24], another regional sustainability strategy for Canterbury. The implementation of the CWMS is still work in progress [25].

\section{RESOURCES/PROCESSES/OUTCOMES/RESPONSE MODEL}

Key technical inputs to the strategy development process included a Regional Environment Report and predictions of the outcomes of alternative strategies. However, the Canterbury Region Environment Report 2008 [26] was set in a sustainability framework rather than a Pressure-State-Response framework. The environment represents one of four well beings under the Local Government Act: environmental, economic, social and cultural. The framework is based on a Resources/Processes/Outcomes/Response model for sustainability. These components are dynamically interrelated. Resources provide the basis for processes, both productive processes and pressures on the environment. Outcomes of processes can also be productive outcomes as well negative impacts on the environment. Outcomes can be linked by positive or negative feedback loops both to processes and to resources (Fig. 1). Responses are the initiatives taken as a result of the outcomes observed.

\footnotetext{
** Runanga are Maori communities based on a marae (tribal meeting place)
} 
Canterbury Region Environment Report 2008 covers the environmental components: the natural capital as the resource component, natural resource management as the process component, the environmental outcomes and the organisational responses to environmental issues. A complementary Community Outcomes Report [27] addressed the outcomes across all four well beings of sustainability: environmental, social, cultural and economic.

This Resources/Processes/Outcomes/Response framework is more holistic compared to the Pressure-State-Response model which is focused on the negative pressures, their adverse effects on the environment and how those effects can be mitigated.

\section{EVOLUTION OF ENVIRONMENTAL INSTRUMENTS}

Table 1 sets out the key environmental instruments that have evolved since the introduction of project level EIA. This starts from the reaction to projects with EIA influencing project design, and environmental management and audit influencing industry operations. There are instruments for putting projects into their regional context with EIA for site selection and environmental rehabilitation for project closure. There are instruments for regional strategic level assessment with SEA on development strategies and SoER on development pressures on the state of the environment. We are now seeing the development of proactive sustainability approaches with regional sustainability strategies for future development pathways and Resources/Processes/Outcomes/Response model considering operational activities from the perspective of all pillars of sustainability. This is an evolution from an emphasis on mitigation to an emphasis on sustainability.

\section{MANAGEMENT OF EFFECTS AT SUSTAINABILITY LIMITS}

Effects-based approaches based on reducing the adverse effects of new development is insufficient to manage resource availability at sustainability limits or the cumulative effects of resource use. As identified in the CWMS there is no capacity for further development unless the cumulative effects of existing development are reduced. The focus of environmental instruments needs to be on the achievement of sustainable outcomes considering all development not just the adverse effects of new development.

Table 1: The evolution of environmental instruments.

\begin{tabular}{|c|c|c|c|}
\hline & $\begin{array}{l}\text { DEVELOPMENT } \\
\text { ACTIVITIES }\end{array}$ & $\begin{array}{l}\text { OPERATIONAL } \\
\text { ACTIVITIES }\end{array}$ & \multirow{5}{*}{$\begin{array}{l}\text { MITIGATION } \\
\nabla\end{array}$} \\
\hline $\begin{array}{l}\text { REACTION TO } \\
\text { PROJECT }\end{array}$ & $\begin{array}{l}\text { EIA in } \\
\text { Project Design }\end{array}$ & $\begin{array}{l}\text { Environmental } \\
\text { Management and } \\
\text { Audit in Project } \\
\text { Operations }\end{array}$ & \\
\hline $\begin{array}{l}\text { PROJECT IN } \\
\text { REGIONAL } \\
\text { CONTEXT }\end{array}$ & $\begin{array}{l}\text { EIA in Site } \\
\text { Selection }\end{array}$ & $\begin{array}{l}\text { Environmental } \\
\text { Rehabilitation }\end{array}$ & \\
\hline $\begin{array}{l}\text { REACTION TO } \\
\text { DEVELOPMENT } \\
\text { STRATEGY }\end{array}$ & $\begin{array}{l}\text { SEA of } \\
\text { Development } \\
\text { Scenarios }\end{array}$ & $\begin{array}{l}\text { State of Environment } \\
\text { Reporting } \\
\text { (PSR model) }\end{array}$ & \\
\hline $\begin{array}{l}\text { PROACTIVE } \\
\text { SUSTAINABILITY } \\
\text { STRATEGY }\end{array}$ & $\begin{array}{l}\text { Regional } \\
\text { Sustainability } \\
\text { Strategy }\end{array}$ & $\begin{array}{l}\text { Resources, } \\
\text { Processes, Outcomes, } \\
\text { Response Model }\end{array}$ & \\
\hline
\end{tabular}


This requires a strategic approach for regional management of development and resource use. It also means existing users having to reduce resource use and the impacts of their use. This places an emphasis on resource allocation and on the allocation of capacity of receiving environments. This has implications for existing use rights and involves consideration of equity in allocation both among existing users, and, between existing users and potential new users. This also involves a change from current resource allocation based on first-come firstserved to merit-based allocation. It also means that any provisions for new entrants will come at the expense of allocations to existing users.

Two examples of approaches to address these types of issues are described below. One is the approach taken in the South African Water Act [28] in areas where water is under stress, e.g. where demands exceed available supply or where water quality is under threat, in other words, at sustainability limits. The other is the management of salinity in the Murray-Darling Basin where sustainability targets have been set requiring reduction in salinity impacts associated with existing use but allowance has been made for new entrants through offsets [29].

The South African Water Act has a provision for the responsible authority to undertake compulsory licensing of any aspect of water use for existing and new users. The process can be undertaken to (a) achieve a fair allocation of water which is under water stress or to achieve equity in allocations; (b) to promote beneficial use of water in the public interest; (c) to facilitate efficient management of the water resource, or (d) to protect water quality. In the reallocation process the responsible authority can consider a wide range of factors including existing lawful uses, investments already made, redress of past discrimination, socio-economic impacts, catchment strategies, effects on the resource and other users, water quality objectives, strategic importance of use, reserves for future use and international obligations, and duration of use.

New Zealand's effects-based legislation (RMA), is far more limited with consent reviews limited to adverse effects better dealt with at a later stage, or, to water and discharge consents when operative regional plans introduce rules for flow rates, rates of water use or water quality standards. The factors that can be considered in resource allocation in the South African legislation are far more comprehensive in relation to sustainability outcomes compared to the first-come first-served allocation principles under the RMA.

Salinity of the River Murray has been a major concern in the Murray-Darling Basin, a very large catchment $\left(1,061,469 \mathrm{~km}^{2}\right)$ involving four states in Australia (Queensland, New South Wales, Victoria and South Australia). A strategy has evolved over the last 30 years to reduce salinity to achieve the target of 800 EC units at Morgan (the offtake for Adelaide's drinking water supply) for 95\% of the time. The Murray-Darling Basin Salinity Strategy is focussed on ensuring that for every new action that puts salt in the Murray River and for delayed salinity impacts of past actions there is another action that reduces salinity impacts of new actions and delayed effects of past actions by the same amount. A key element of the Strategy is two salinity registers: Register A for new actions since the signing of the Murray-Darling Basin Agreement, and, Register B for the delayed salinity impacts of actions prior to the signing of the Agreement. The Salinity Registers are a credit and debit based salinity accounting system which tracks actions that are assessed to have a significant effect on river salinity. A significant effect is defined as a change in average daily salinity at Morgan that will be at least $\pm 0.1 \mathrm{EC}$ by the year 2100 . Salinity registers provide the primary record of accountability for actions that affect river salinity.

Salinity credits (reductions in salinity) can be achieved by investing in salt interception schemes, improving irrigation management to reduce saline drainage, ceasing irrigation, and increasing environmental flows in rivers. Salinity debits (increases in salinity) primarily occur 
through new irrigation development. Salinity impact assessments estimate average annual salinity debit or credit by modelling effects of actions over a benchmark period (1975-2000).

Each State is required to prepare annual accounts to demonstrate that there are salinity credits to offset salinity debits. There is also a requirement to meet "end-of-valley salinity targets" for major tributaries, e.g. in Victoria this is a delegated responsibility of Catchment Management Authorities. Salinity credits can be earnt through joint works where all States contribute to the cost of salinity reduction measures (primarily salt interception schemes) or through measures undertaken within the State. While States are responsible for the costs, the cost of the credits is passed on to the beneficiaries of the credits through salinity levies. The financial cost per EC unit is determined annually. For example, in Victoria charges are imposed on new water use licences in salinity impact zones to fund measures that will offset the salinity impact on the river as a result of increased water use. Detailed hydrogeological assessments underpin the salinity impact zones and the capital charges reflect the estimated salinity impact caused by irrigation in the zone.

The implementation of the Salinity Management Strategy has led to a reduction in modelled 95 percentile salinity at Morgan over the benchmark period from 1,050 EC in 1988 to $710 \mathrm{EC}$ in 2015.

\section{CONCLUSIONS}

The paper describes the evolution of key environmental instruments from project EIA to regional sustainability strategies. While effects-based legislation is powerful in mitigating adverse effects of projects, it is insufficient when sustainability limits have been reached. There is a need for proactive regional strategies to address sustainability limits rather than reactive assessments of new developments. Furthermore, effects-based legislation may constrain a sustainable pathway for future development. Approvals of existing developments, for resource use or pollution discharge, provide legal rights for existing users. This can constrain options for increased resource efficiency or pollution reduction of existing development. Effects-based assessment, which focuses on incremental effects of new development, is unable to address these issues for existing development. To achieve sustainable development there is a need to go beyond reactive approaches, such as EIA. This involves generating proactive strategies for environmental improvement together with economic and social development. The concept of regional sustainability strategies, such as CWMS and the Canterbury Biodiversity Strategy, are examples of trying to reverse the trends of ongoing degradation. There is also a need for new action-forcing mechanisms such as reallocation in stressed environments on the basis of merit or mechanisms for implementing offsets for the impacts of new development.

\section{REFERENCES}

[1] National Environmental Policy Act of 1969, Public Law 91-190 91st Congress S.1075, Jan 11970.

[2] South Australian Environmental Protection Act, 1993.

[3] Western Australian Environmental Protection Act, 1986.

[4] Jenkins, B.R., Ways environmental factors can influence projects. Transactions of Multi-Disciplinary Engineering, GE12, 1, pp. 1-5, 1988.

[5] Jenkins, B.R., Environmental audit - how to do it. Environmental Protection - Striking the Balance, Adelaide, 1991.

[6] Department of Aviation, Second Sydney Airport Site Selection Programme: Draft Environmental Impact Statement, Kinhill Stearns: Sydney, 1985. 
[7] Penrith Lakes Development Corporation, Penrith Lakes Scheme Development Application 2 (DA2) Extraction and Rehabilitation Programme, Statement of Environmental Effects, Kinhill Stearns: Sydney, 1986.

[8] Jenkins, B.R., National Council Approaches - Implications for Site Remediation. Keynote Address 1999 Contaminated Site Remediation Conference, Fremantle, 1999.

[9] OECD , Environmental Indicators: Development, Measurement and Use, OECD: Paris, 2003.

[10] Dalal-Clayton, B. \& Sadler, B., Strategic Environmental Assessment: a Sourcebook and Reference Guide to International Experience, Earthscan: London, 2005.

[11] Victorian Environment Effects Act, 1978.

[12] South Australian Environmental Protection Act, 1993.

[13] New Zealand Resource Management Act, 1991.

[14] Aitchison-Earl, P., Scott, D. \& Sanders, R., Groundwater allocation limits: guidelines for the Canterbury Region. report U04/02 Environment Canterbury, Christchurch, 2004.

[15] Environment Court, Lynton Dairy v Canterbury Regional Council NZ Resource Management Act, Decision C108/2005.

[16] http://ecan.govt.nz/services/on-line-services/monitoring/groundwater-allocation/ Pages/groundwater-allocation-summary.aspx

[17] Joint Decision and Recommendation of Independent Commissioners, Consent applications by Central Plains Water Trust, 2010.

[18] Canterbury Water, Selwyn Waihora ZIP Addendum, Environment Canterbury, Christchurch, 2013.

[19] Jenkins, B.R., Recent Western Australian Experience: Management of Resources and Sustainable Development - Implications for the RMA, RMLA Canterbury Branch Seminar, Christchurch, 2004.

[20] Canterbury Water, Canterbury Water Management Strategy: Strategic Framework, Environment Canterbury, Christchurch.

[21] Jenkins, B.R., Water Allocation in Canterbury, NZ Planning Institute Annual Conference, Palmerston North, 2007.

[22] Jenkins, B.R. \& Henley, G., Collaborative Management: Community Engagement as the Decision-making Process. The Australasian Journal of Natural Resources Law and Policy, 17(2), pp. 135-152.

[23] Jenkins, B.R., Russell, S., Sadler, B. \& Ward, M., Application of sustainability appraisal to the Canterbury Water Management Strategy, Australasian Journal of Environmental Management, 21(1), pp. 83-101, 2014.

http://dx.doi/10.1080/14486563.2014.880383

[24] Environment Canterbury, A Biodiversity Strategy for the Canterbury Region, Environment Canterbury: Christchurch, 2008.

[25] Jenkins, B.R., Progress of the Canterbury Water Management Strategy and some emerging issues. Agricultural and Resource Economics Society Conference, Lincoln University, 2013.

[26] Environment Canterbury, Canterbury Regional Environment Report , Environment Canterbury, Christchurch, 2008.

[27] Environment Canterbury, Environment Canterbury Community Outcomes Report 2006-2008, Environment Canterbury, Christchurch.

[28] Republic of South Africa, National Water Act, Government Gazette, 1998.

[29] Murray-Darling Basin Ministerial Council, Basin Salinity Management 2030 (BSM 2030), Murray-Darling Basin Authority: Canberra, 2015. 